DOI https://doi.org/10.15589/znp2020.2(480).8

УДК 621.31

\title{
EVALUATION AND PREREQUISITES FOR BUILDING INTELLECTUAL OF ENERGY ENVIRONMENTS BASED ON PHOTOVOLTAIC ELECTRICITY GENERATION SYSTEMS
}

\section{ОЦНКА ТА ПЕРЕДУМОВИ ДЛЯ ПОБУДОВИ ІНТЕЛЕКТУАЛЬНИХ ЕНЕРГЕТИЧНИХ СЕРЕДОВИЩ НА ОСНОВІ ФОТОВОЛЬТАЇЧНИХ СИСТЕМ ГЕНЕРАЦІЇ ЕЛЕКТРОЕНЕРГІї}

\author{
Serhii P. Denysiuk \\ spdens@ukr.net \\ ORCID: 0000-0002-6299-368 \\ Pavlo V. Sokolovskyi \\ ps 8@ukr.net \\ ORCID: 0000-0002-0113-4479
}

\author{
С. П. Денисюк, \\ докт. техн. наук, професор
}

П. В. Соколовський,

$\mathrm{PhD}$ студент
National Technical University of Ukraine "Igor Sikorsky Kyiv Polytechnic Institute”, Kyiv
Національний технічний університет Украӥни «Київський політехнічний інститут імені Ігоря Сікорського», м. Київ

\begin{abstract}
The article deals with the state of renewable energy in Ukraine as a key unit in the construction of future energy Smart Grid systems.

The purpose of the work is to evaluate and analyze the work of the assistant program in the search for and implementation of projects for the construction of solar power plants based on private solar systems. The operation of such systems will directly depend on the mode of operation of the fryer. In order to verify the results of the assistant program, a detailed comparative assessment was performed with the work of both real mini SPP complexes on the basis of the Institute of Energy Conservation and Energy Management and paid software complexes for modeling SPP. The differences in the calculations are minimal, the simulation results are close to the real ones (discrepancy $8,72 \%$ ), provided that the assistant program is a complete calculation module. The state of development of the RES sector in Ukraine is described, namely PV stations in the energy structure of the United Energy System of Ukraine. Further prospects of development in relation to world tendencies are determined. The energy and economic criteria accession are described. The foreign construction experience and implementation of green technologies in energy systems on the basis of such projects as NYSEG and SCA for its further scientific research and testing are described. Using the Matlab Simulink environment, modeling the work on the PV module with the selection of its main dependences on the generalized indicator of solar insolation is constructed and described. The obtained statistical data and the price of using PV systems indicate a stable and fast-growing demand for their distribution and installation.

Results. Real indicators and assessment of the use of private solar power plants are given.

Scientific novelty. The use of software to assess the level of efficiency of private SPP close to the real accuracy of calculations.

Practical importance. The materials of this work can be used to enhance the efficiency and productivity of both SPP at the construction stage and already built.

Key words: UES of Ukraine; renewable energy sources; PV system; energy storage; flexible generation; prosumer; Smart Grid; Solar power plant.

Анотація. У статті йдеться про стан відновлювальної енергетики України як ключової одиниці в побудові майбутніх енергетичних систем Смарт Грід.

Мета - оцінка й аналіз роботи програми-асистента в пошуку та реалізації проєктів 3 побудови сонячних електростанцій на базі приватних сонячних систем. Робота таких систем прямим чином залежить від режиму роботи споживача.

3 метою достовірності отриманих результатів роботи програми-асистента було виконано детальну порівняльну оцінку з роботою як реальних комплексів міні-СЕС на базі Інституту енергозбереження та енергоменеджменту, так і платних програмних комплексів із моделювання сонячних електростанцій. Розбіжності в розрахунках мінімальні, результати моделювання є близькими до реальних (розбіжність - 8,72\%), за умови, що програма-асистент є повністю розрахунковим модулем. Охарактеризовано стан розвитку сектора відновлюваних
\end{abstract}




\section{ЕЛЕКТРОЕНЕРГЕТИКА, ЕЛЕКТРОТЕХНIКА ТА ЕЛЕКТРОМЕХАНІКА №2 2020}

джерл енергії в Україні, а саме PV-станцій, в енергетичній структурі об'єднаної енергетичної системи України. Описані енергетичні й економічні критерії такого приєднання. Проаналізовано іноземний досвід побудови та впровадження зелених технологій в енергетичні системи таких проєктів, як NYSEG та SCA, для подальшого його наукового дослідження та випробування. Описано роботу PV-модуля з виділенням його основних залежностей від узагальненого показника сонячної інсоляції в середовищі Matlab Simulink. Отримані дані вказують на всі передумови можливості широкої участі приватних PV-систем забезпечення електроенергією як основного активу функціонування Energy Smart Community.

Результати. Наведено реальні показники й оцінку використання приватних сонячних електростнцій.

Наукова новизна. Використання програмного комплексу для оцінки рівня ефективності приватних сонячних електростанцій близької до реальної точності розрахунків.

Практична значимість. Матеріали цієї роботи можуть бути використані з метою підвищення ефективності та продуктивності роботи сонячних електростанцій як на етапі будівництва, так і вже побудованих.

Ключові слова: екологічна безпека; ризик; акваторія; забруднення; антропогенний вплив.

\section{АНАЛІЗ ОСТАННІХ ДОСЛІДЖЕНЬ І ПУБЛІКАЦЙ}

Реалізація енергетичного переходу, енергетичної трансформації вимагає розробки нових механізмів та заходів розвитку енергетичного сектора $[1 ; 2 ; 6$; 8; 11-13]. Проведений аналіз показав, що реалізація політики 3D - декарбонізації, децентралізації та диджиталізації - енергетичного сектора повинна здійснюватися з урахуванням, з одого боку, специфіки країни, регіону (області), міста чи району (локальних спільнот), а з іншого - складу обладнання та режимів роботи систем генерації, передачі, розподілу та споживання енергії.

У багатьох випадках для виділених рівнів: 1) країна; 2) регіон (область); 3) місто; 4) район (локальна спільнота) - сучасні проблеми енергетики мають розглядатися комплексно з урахуваням, звичайно, рівнів деталізації, виділення значущих елементів систем і процесів $[1 ; 8 ; 13]$. Так, на рівні країни для об'єднаної енергетичної системи (далі - ОЕС) України натепер постали нагальними завдання забезпечення оптимального використання генерації відновлюваних джерел енергії (далі - ВДЕ), насамперед вітрових (далі-BЕС) та сонячних (далі-СЕС) електростанцій $[1 ; 4 ; 15]$. Одним із напрямів вирішення цих завдань $\epsilon$ впровадження технологій гнучкої генерації [14; 17]. 3 іншого боку, процеси у системах передачі та розподілу енергії (передусім електроенергії) оптимізуються з урахуванням положень концепції Smart Grid $[1 ; 4 ; 13]$.

За даними Приватного акціонерного товариства «Національна енергетична компанія «Укренерго»» (далі - НЕК «Укренерго»), лише протягом 2019 р. встановлена потужність ВЕС і СЕС у нашій країні збільшилася у 2,7 рази та досягла показника 4,7 ГВт [15]. Станом на початок квітня 2020 р. вона вже збільшилася до 5,2 ГВт, цей обсяг більший за той, що енергосистема України сьогодні може прийняти без серйозних відхилень у роботі. Адже максимально в робочий день ОЕС України може прийняти не більше 4,7 ГВт встановленої потужності ВЕС, а для суботи/неділі та святкових днів максимальний обсяг взагалі знижується до 3,5 ГВт. Водночас обидва показники можуть знижуватися залежно від коливань електроспоживання, яке, у свою чергу, залежить від температури повітря й активності споживачів - великих підприємств.

До кінця 2020 р. встановлена потужність ВДЕ може збільшитися ще у півтора рази - до 7,4 ГВт. Стрімке збільшення обсягів ВДЕ вимагає термінових заходів для підвищення гнучкості енергосистеми. У Звіті з оцінки відповідності (достатності) генеруючих потужностей НЕК «Укренерго» для цього надає такі рекомендації [15]:

- ввести зобов'язання для інвесторів у ВДЕ забезпечувати для своїх електростанцій будівництво високоманеврової генерації або Energy Storage в обсягах приблизно 20\% від встановленої проєктної потужності станцій ВДЕ;

- якнайшвидше запровадити відповідальність ВДЕ за небаланси;

- побудувати вже у 2021 р. 2 ГВт нових маневрових потужностей зі швидким стартом і систем акумулювання енергії потужністю 2 ГВт;

- обсяги річних квот підтримки суб'єктів господарювання, які виробляють електричну енергію з альтернативних джерел енергії, не повинні перевищувати можливості ОЕС України щодо їх повної інтеграції без обмежень видачі потужності.

\section{МЕТА ДОСЛІДЖЕННЯ}

Розробка методології оцінки ефективності використання ВДЕ у складі активних споживачів (просюмерів) на прикладі фотовольтаїчних систем генерації електроенергіï.

\section{ОСНОВНИЙ МАТЕРІАЛ}

В умовах пріоритетного розвитку зеленої енергетики та стрімкого нарощування частки ВДЕ у країні зростає потреба в якісно нових принципах планування розвитку енергосистеми $[1 ; 4 ; 5-8 ; 16]$. Водночас на тлі високих темпів зростання СЕС і ВEC зростає потреба в балансуванні іхньої змінної потужності [14; 15]. Найкращого універсального способу забезпечити таке балансування не існує, однак завжди 
є специфіка місцевих умов і особливості технологій, які треба враховувати під час планування розвитку енергосистеми, а також $є$ різні потреби в енергосистеми. Ідеться про первинне, вторинне та третинне регулювання, а також такий новий тип резервування, як компенсація похибки прогнозу ВДЕ. Усі ці потреби можна поєднати в одному понятті - потребі у гнучкості енергосистеми [14]. У широкому сенсі є чотири види джерел гнучкості: гнучка генерація, мережеві рішення (це перетоки, інтерконектори, розумні мережі), регулювання попиту, а також системи накопичення енергії. Найбільш ефективним способом підвищити гнучкість $є$ комбінація різних технологій.

Інженери компанії Wärtsilä проаналізували структуру об'єднаної енергосистеми України 3 урахуванням цього й інших викликів [15; 17]. Результати дослідження були представлені у звіті «Гнучкість для енергосистеми майбутнього. Вирішення українського «зелено-вугільного» парадокса». Для балансування зростаючих обсягів відновлюваної енергії і стабільного електропостачання без збоїв та неочікуваних відключень потрібно керувати цим малопередбачуваним виробництвом. Можливі джерела гнучкості для України (згідно з інформацією Wärtsilä Energy): ГЕС/ ГАЕС; інтерконектори; накопичувачі; маневрені ТЕС. Спеціалісти Wärtsilä моделювали варіанти повністю відновлюваних енергосистем. У жодному зі сценаріїв неможливо досягти надійного електропостачання та стійкості лише завдяки використанню СЕС та ВЕС. У кожному разі мають бути наявні три елементи:

1) потужність базового навантаження, чию роль відіграватимуть саме СЕС, ВЕС і біостанції;

2) системи накопичення енергії для виконання двох функцій - короткострокового балансування ВДЕ, або регулювання частоти, та добового переносу енергії, тобто акумулятори потужності й акумулятори енергії;

3) гнучка або маневрена генерація для резервування на більш тривалі, ніж кілька годин, інтервали, наприклад, на випадок різкого падіння виробництва ВДЕ внаслідок сезонних чинників чи негоди.

Водночас встановлена потужність кожного із трьох видів $є$ кратною щодо потужності пікового споживання [15]. Наприклад, щоб забезпечити потребу в енергії лише завдяки ВДЕ, треба мати приблизно п'ятикратну потужність власне ВЕС, СЕС та біо, плюс чотирикратну потужність батарей і однократну - маневреної генерації. Тобто якщо пікове споживання 100 ГВт, то треба мати приблизно 500 ГВт ВДЕ, 400 ГВт батарей і 100 ГВт маневрової потужності.

Натепер з урахуванням положень клієнтоорієнтованої роботи сучасних енергосистем велика увага приділяється споживачам енергоресурсів (споживачів останньої милі, англ. last mile consumers) [4-7]. Адже тенденції розвитку тих чи інших секторів енергоспоживання зумовлені розробленням сучасних технологій споживання, інформаційно-комунікаційних технологій, їх поєднання на системному рівні. До цього додається розвиток (розширення) функціональних можливостей споживачів, зокрема завдяки наявності власних джерел енергії, виступати в ролі просюмер (активних споживачів), формування сучасних відносин, зокрема, поява нових бізнес-процесів, як у середині групи споживачів, так і між різними групами споживачів [3; 4]. Тут варто відзначити такі перспективні напрями досліджень, як розгляд постачання електроенерії як послуги $[9 ; 10 ; 16]$ та формувавання агрегаторів навантажень $[3 ; 5 ; 7]$.

Енергія як послуга (англ. Energy as a Service (далі - EaaS)) - це «пакетна» модель обслуговування, у межах якої клієнту надається апаратне і програмне забезпечення й енергетичні послуги [10; 16]. Рішення категорії EaaS повинні включати в себе послуги 3 керування споживанням і підвищення енергоефективності, сприяти впровадженню ВДЕ й інших децентралізованих джерел енергопостачання, а також оптимізувати баланс між попитом і пропозицією на ринку електроенергії. Головна перевага для споживача полягає у спрощенні пакета послуг, незважаючи на збільшення їх розмаїття.

Для такого сценарію потрібна наявність матеріальної, цифрової та комунікаційної інфраструктури, а це означає, що на ринку EaaS можуть бути різні категорії гравців: комунальні і промислові підприємства, технологічні компанії, великі енергетичні компанії, спеціалізовані постачальники поновлювані енергії, телекомунікаційні компанії та молоді інноваційні компанії (стартапи).

Нині енергетика стоїть на порозі галузевої конвергенції, яка вже охопила індустрії роздрібної торгівлі, засобів масової інформації та промислові виробництва. Зі зниженням витрат на виробництво енергії, розвитком мікрогенераціі та цифрових платформ для обслуговування енергопродуктів. Енергетичний ринок завтрашнього дня - це розподілена і змінна генерація, двостороння передача, горизонтальна мережева структура $[10 ; 16]$. Енергія як послуга може бути представлена як сума технологій і процесів, пов'язаних з енергією:

- технології: інтернет-речей (IоT), інформаційна безпека, датчики і засоби управління, хмарні платформи, 5G, когнітивні технології / роботизація, блокчейн, передова аналітика, дрони і роботи, доповнена реальність;

- процеси, пов’язані 3 енергією: декарбонізація під тиском регулятором, розвиток ВДЕ, енергоефективність, вітрові та сонячні установки, електротранспорт, біологічне і біохімічне паливо, паливні елементи і мікротурбінні технології, геотермальні установки, великі енергосховища, коригування портфельних інвестицій / консолідація ринку.

Зміни в моделях роботи енергомереж приведуть до появи великої різноманітності нових бізнес-моделей [9]. 


\section{ЕЛЕКТРОЕНЕРГЕТИКА, ЕЛЕКТРОТЕХНІКА ТА ЕЛЕКТРОМЕХАНІКА №2 2020}

Як приклад коротко розглянемо розвиток локальних енергетичних ринків. Інтеграція набагато ширшого масиву розподілених ресурсів і розвитку технологій, які дозволяють у режимі реального часу отримувати дані про попит і пропозицію, дозволяє споживачам енергії, які водночас є їі виробниками (просюмери), генерувати, запитувати і зберігати енергію і пропонувати іiі іншим учасникам, а не тільки поставляти надлишки назад у мережу. Щоб збалансувати попит і пропозицію з урахуванням поточних розцінок, потрібно підвищити гнучкість і швидкість роботи.

Багато міст, районів і регіонів уже реалізують енергетичні проєкти для комплексного обслуговування тих чи інших об'єктів. Такі ініціативи передбачають децентралізовану генерацію, постачання й управління поставками електроенергії. Як приклади можна навести Р2P-платформу компанії "Brooklyn Microgrid” (бруклінські мікромережі) у США, пілотний проєкт енергетичної компанії "Horizon Power" щодо забезпечення розподіленими енргетичними ресурсами регіон Пілбара в Австралії, автономну ВДЕ-енергосистему на острові Самсо в Данії, а також фінансований Свропейським Союзом пілотний проєкт автономної сонячної і вітряної електростанції в селищі Сімріс у Швеції [10].

Поширення комунальних сонячних електростанцій або компактних комунальних енергомереж - це частина тренда, адже мікромережі на ВДЕ можуть бути екологічніше, дешевше i надійніше централізованих мереж, особливо у віддалених районах [9; 16]. Загальну координацію складної структури будуть створювати:

- на рівні електромережі - нейтральний посередник, за допомогою якого учасники відкритих конкурентних ринків зможуть купувати / продавати енергію системі;

- на рівні житлового району - дану роль може взяти на себе агрегатор, який через оператора розподільної системи (DSO) буде забезпечувати енергопостачання автоматизованих будівель або комплексу будівель, об'єднаних в єдину віртуальну електростанцію, що забезпечить вирівнювання і контроль навантаження;

- на рівні споживачів - загальну координацію може здійснювати постачальник послуг, який за фіксовану щомісячну плату буде допомагати своїм комерційним або промислових клієнтам виконувати вимоги і добиватися поставлених цілей щодо енергопостачання, енергоефективності, створення резервних потужностей, забезпечення відмовостійкості, а також використання ВДЕ і скорочення викидів вуглецю.

Енергія як послуга (EaaS) - це інноваційна бізнес-модель, яка передбачає надання пакетних послуг в області енергопостачання за допомогою нових технологічних і фінансових розробок. Модель
«<...> як послуга»- модель представлення різних комплексних рішень, що включають апаратне і програмне забезпечення і послуги того чи іншого роду. Вигоди створюються завдяки об'єднанню в єдиний пакет різних елементів, які зазвичай продаються окремо.

Рішення в рамках концепції $\mathrm{EaaS}$ дозволяють управляти енергоспоживанням і підвищувати енергоефективність, впроваджувати ВДЕ й інші децентралізовані джерела енергії, а також оптимізувати баланс між енергоспоживанням і енергопостачанням. Обслуговування за моделлю $\mathrm{EaSS}$ може включати в себе рішення для локального зовнішнього енергопостачання об'єктів, а також для зберігання й управління енергією. Крім того, постачальник надає послуги стратегічного керівництва 3 питань закупівель, фінансування, експлуатації й обслуговування всього енергетичного портфеля клієнта. Управління енергоспоживанням передбачає традиційні послуги з підвищення енергоефективності та балансування навантаження на енергомережу з метою розподілу енергоресурсів з урахуванням попиту.

Головна перевага для клієнтів (споживачів) полягає у спрощенні пакета послуг, незважаючи на зростання їх різноманіття. У разі укладання договору за моделлю EaaS клієнт може позбавити себе від необхідності залишатися в авангарді інноваційних технологій, передавши відповідальність постачальникам, які надають послуги з проєктування, монтажу, обслуговування й управління відповідним обладнанням. Зазначимо, що ринок EaaS функціонує на базі послуг ЕСКО, але пропонує більше варіантів енергопостачання. Інтегрує різні варіанти енергопостачання на різних об'єктах і керує ними за допомогою цифрових технологій [9].

Для функціонування ринку EaaS потрібна певна матеріальна, цифрова та комунікаційна інфраструктуpa, а це означає нові можливості для широкого спектра гравців. Завдяки багаторічному досвіду володіння й експлуатації основних фізичних активів різноманітні комунальні підприємства матимуть природну перевагу на цьому ринку. Розробники рішень в області сонячної енергетики, як-от SunPower i SunRun, зараз нарощують свої можливості щодо створення комплексних пакетів продуктів і послуг для роздрібних і корпоративних клієнтів [10]. Постачальники EaaS-послуг будуть пропонувати великий вибір гнучких рішень, розроблених з урахуванням потреб клієнтів, зокрема встановлювати стандарти інтеграції продуктів для різних сегментів / категорій клієнтів. Трансформація енергетичних продуктів і послуг повинна здійснюватися з урахуванням динаміки зовнішніх ринків і розширення можливостей самої компанії. У результаті такої трансформації виникне інтегрований енергоменеджер, або координатор енергомережі.

В Україні сонячна енергія реалізується насамперед у промислових масштабах або серед приватних 
споживачів. У зв'язку із запуском зелених тарифів у 2008 р. (діє до 2030 р.) і ухваленням законопроєкту про перехід до нового механізму стимулювання реалізації зеленого проєкту - аукціонів, а також удосконалення інвестиційних програм країн-партнерів у сфері розвитку зелених технологій [18].

Після довготривалих переговорів 3 інвесторами 11 червня 2020 р. уряд таки ухвалив зелений Меморандум щодо так званої добровільної реструктуризації зелених тарифів.

Увечері того ж дня свої підписи під документом поставили Прем'єр, в. о. Міністра енергетики та представники двох профільних асоціацій.

У рамках Мемомрандуму з виробниками зеленої електроенергії Кабмін зобов'язався до кінця 2021 р. остаточно погасити наявну заборгованість перед ВДЕ-інвесторами, яка становить 14 млрд грн. Перший пункт Меморандуму - виробники погодилися на зменшення зелених тарифів без пролонгації строку дії договорів. Тобто підтримка ВДЕ, як і планувалося, завершиться 31 грудня 2029 р. Для сонячних електростанцій потужністю понад 1 МВт, що були введені в експлуатацію до 2020 р., тариф пропонується урізати на 15\%, до 1 МВт - на 10\%. Водночас для СЕС і ВЕС, уведених в експлуатацію у 2020 р. та пізніше, зниження становитиме ще 2,5\%. Крім того, відповідно до Меморандуму, посилюється відповідальність генерації за небаланси. Так, виробники ВДЕ нестимуть фінансову відповідальність за всі похибки прогнозування із 2021 р. на рівні $50 \%$, iз 2022 p. - 100\%. Зі свого боку влада взяла на себе зобов'язання запропонувати та підтримати необхідні для реалізації згаданих домовленостей зміни до законів до 1 серпня поточного року. Другий пункт зобов'язує владу в подальшому не змінювати умови підтримки виробників електроенергії із зеленим тарифом. Третій - запровадити квоти для підтримки зелених та забезпечити проведення аукціонів з їх розподілу. По-четверте, через місяць після того, як зміни набудуть чинності, держава обіцяє повністю та своєчасно розраховуватися за електроенергію з виробниками ВДЕ та не допускати боргів у подальшому [20].

За перший квартал 2020 р. було встановлено 2171 сонячну електростанцію, і даний показник переважає минулорічний (65 МВт). Лідерами стали Дніпропетровська, Тернопільська та Київська області. Станом на 1 квітня 2020 р. сумарна кількість станцій уже більша 24 тисяч, а загальна потужність усіх СЕС становить 618 МВт. У проміжку із 2016 р. до початку квітня 2020 р. загальна генерація всієї кількості домашніх електростанцій, які підключені до зеленого тарифу, становить 484258 МВт! А тільки за перший квартал цього року виробіток становив майже 100 тис. МВт*год [21].

Частка приватних домогосподарств у загальному обсязі нових зелених енергопотужностей поки незна- чна - приблизно 5-10\%, але темпи встановлення СЕС приватниками вражають.

Реалізація розвитку сектора СЕС активно просувається завдяки законодавчим гарантіям як для національних, та і для міжнародних інвесторів, яким гарантують повернення вкладених інвестицій.

Для інвесторів у проєкти ВДЕ України передбачаються такі законодавчі переваги:

- встановлений один із найвищих у світі зелених тарифів, за яким держава гарантовано викуповує вироблену зелену енергію в інвесторів до 2030 р. і який прив'язаний до курсу євро для захисту інвесторів від інфляційних ризиків. Водночас за умови використання українських технологій на об'єктах ВДЕ передбачена додаткова надбавка до зеленого тарифу до 10\%;

- iз 2015 р. також були збільшені потужності генерації зеленої енергії для приватних домогосподарств, які претендують на отримання «зеленого» тарифу, з 10 кВт до 30 кВт. Це дозволило приватникам розглядати інвестиції в зелену енергію не тільки як модний тренд, але і як бізнес-проєкт. Наприклад, у 2015 р. середня окупність сонячної електростанції потужністю 30 кВт, вартістю до 40 тисяч євро, становила, за оцінками учасників ринку, до 7 років. А окупність порівняної за вартістю інвестицій однокімнатної квартири була на рівні 10-15 років;

- термін дії зеленого тарифу - до 2035 р., що дає не тільки економічну, а й технічну перспективу для розвитку галузі.

Зелені інвестицій є міжнародними гарантованими зобов'язання України перед Свропейстким Союзом щодо виконання Договору про заснування Енергетичного Співтовариства. Для цього у 2017 р. Кабінетом Міністрів України ухвалена Енергетична стратегія України. Згідно із цією Стратегією, до 2035 р. Україна планує збільшити частку відновлюваної енергетики у своєму енергобалансі до $25 \%$, за ії частки станом на третій квартал 2019 р. - 3-4\%, що є суттєвим кроком України на шляху до лібералізації енергоринку.

Такі зміни у структурі енергобалансу України в бік генерації відновлюваної енергії пояснюються бажанням нашої країни стати учасником єдиного європейського ринку електроенергії та приєднатися до європейської мережі системних операторів передачі електроенергії ENTSO-E. Інакше кажучи, на державному рівні в Україні задекларована мета отримати можливість експортувати свою електроенергію в Свропейський Союз. Зокрема, реалізація енергетичної стратегії України передбачає потужність передачі електроенергії в / з ENTSO-E в обсязі 4 ГВт після синхронізації енергоринків.

Сам же Свропейський Союз задекларував досягнення частки альтернативної енергії у зведеному енергобалансі на рівні $20 \%$ до 2020 р., а до 2030 p. Свросоюз має наміротримувати вже $32 \%$ енергії з відновлюваних джерел [22]. 


\section{ЕЛЕКТРОЕНЕРГЕТИКА, ЕЛЕКТРОТЕХНІКА ТА ЕЛЕКТРОМЕХАНІКА №2 2020}

Упровадження в енергетичну систему України PV-систем і зміни економіко-споживчого мислення споживачів привели до появи та функціонування таких моделей споживачів, як prosumer та prosumage. Це є передумовою для зміни базової стратегії функціонування енергосистем і енергоринку, створення нових форматів взаємодії в рамках «споживач енергопостачальна компанія», які описані в понятті Energy Smart Community (далі - ESC) [23].

Головна мета ESC полягає в підвищенні рівня використання енергії з боку споживача та стабілізації роботи як малих, так і регіональних систем розподілу. Наприклад, оптимізація добового графіка електроспроживання: зниження дефіциту електроенергії в пікові години, зменшення обсягів недовикористаної електроенергії в години «нічного провалу» тощо. Концепція ESC завдяки економічним стимулам, гнучкості поведінки споживачів і впровадженню джерел розосередженої генерації (Distributed Energy Resources - DER) та ключових елементів концепції технологій Smart Grid передбачає поступове зниження залежності енергетичної галузі від традиційних джерел енергії. Головна роль в ESC відведена розвитку інвестиційної обізнаності споживачів, а саме використання інтегрованого системного планування для переходу до ефективних бізнес-моделей в енергетичній сфері [24].

Прикладом побудови розумної спільноти $є$ пілотний проєкт, розроблений та реалізований компанією "New York State Electric and Gas" (далі - NYSEG) для вивчення потенціалу використання інтелектуальних лічильників та інших сучасних технологій модернізації енергетичних мереж. 12400 споживачів електроенергії в окрузі Томпкінс штату Нью-Йорк отримують найбільш точні показники споживання енергії для більшого розуміння власного споживання енергії. За допомогою локального програмного онлайн-інструменту, через індивідуальний канал доступу, надається доступ до даних щодо споживання енергії в режимі реального часу, попереджень щодо ліміту споживання, порад стососвно економії електроенергії [25].

Інший приклад автономної системи забезпечення електроенергією - острів Аруба (Південь Кариб- ського моря). Автономність незалежного енергетичного об'єднання Smart Community Aruba забезпечується на базі 20 будинків, розташованих в одному мікрорайоні (уведений в експлуатацію у 2017 р.). Завдяки тропічному клімату та сонячній активності понад 2000 годин, розміщенню на кожному будинку сонячних електростанцій побудований один із найбільших тестових стендів, на базі якого проводиться демонстрація та перевіряються питання: стійкості PV-систем, дослідження поведінки споживачів, проблеми відходів, накопичення енергії, раціонального іiі використання згідно з тарифною політикою. У проєкті запланований перехід енергосистеми всього острова до моделі Smart Community Aruba до 2030 р. Нині об'єднання із 20 будинків, поєднаних єдиною системою Smart Grid, служить для залучення інвестицій та перевірки роботи різних техніко-економічних параметрів [26].

Доцільно розрізняти три режими роботи приватних домогосподарств, що характеризуються наявністю фотостанцій та / або накопиченням електричної енергії (на рис. 1 зображено три основні режими систем енергопостачання, що функціонують удома) [25; 26].

На рис. 3 показані режими роботи локальних систем електропостачання із PV-системами: (a) поки представлено споживання електроенергії з електромережі - базову модель (модель споживача) можна охарактеризувати за допомогою систем ESS (Energy Storage System - ESS) для покриття пікових потреб в енергоносіях і тарифних стимулів на енергоресурси як ефективні стимули до економії енергії та мінімізації витрат на придбання електроенергії за двота тризонними ставками; (b) PV-система разом зі споживанням мережі - описує процес максимізації власного споживання електроенергії від сонячної станції та мінімізації споживання мережі (Prosumer: PROfessional i conSUMER, або PROducers + conSUMERS, активний споживач або просюмер); (c) режим Procumage (PROducers + CONSUMer + storAGE, виробник - споживач-сховище (накопичувач)), де можна змінити традиційну роль будинків із власним накопиченням енергії. Упровадження концепції Prosumage дозволяє змінити типові будинки

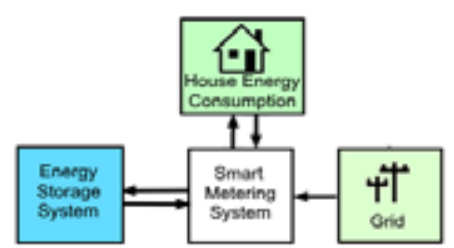

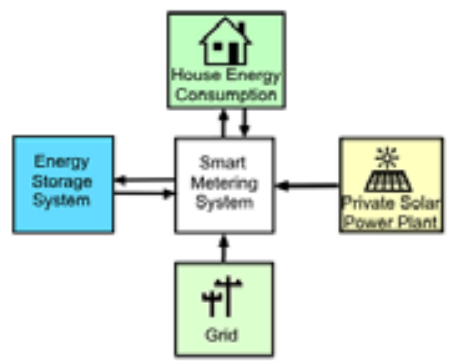

b

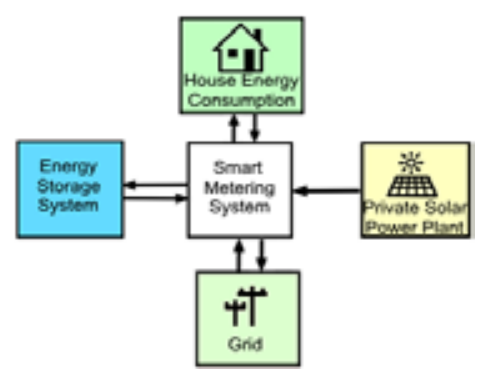

c

Рис. 1. Режими роботи приватних домогосподарств: (a) - споживання електроенергії з мережі; (b) - споживання в системі PV + мережа; (c) -режим Prosumage (стрілки вказують напрямок потоку потужності) [13] 
на рівну частку ринку електроенергії, що є важливим кроком у переході до моделі місцевої енергетичної спільноти. Режим Proumage описує приватні домогосподарства із системами ВДЕ, які працюють як для споживання електроенергії з мережі, так і для іiі продажу за зеленими тарифами [27], щоб максимізувати прибуток. Цей режим є прикладом майбутніх змін в енергетиці і вимагає локальної інфраструктури модернізації енергії та систем управління. Він характеризується мінімальним обмеженням власної генерації та споживанням з мережі завдяки пристрою зберігання електричної енергії, де споживач водночас $\epsilon$ регулятором. 3 урахуванням цілковитого майбутнього переходу електромережі до аукціонної системи закупівлі електроенергії з відновлюваних джерел ця модель найбільш адаптована завдяки своїй гнучкості. Активний розвиток Prosumage в середині 2020-х pp. прогнозується в результаті зменшення систем економії витрат.

У першому та другому режимах $(\mathrm{a}, \mathrm{b})$, показаних на рис. 3, розповсюджувачі, які реагують на зміни енергетичного ринку та впливають на енергетичний ринок шляхом систематичних дій і реакцій, спрямованих на мінімізацію витрат та збільшення власної (та / або) колективної віддачі. У третьому режимі prosumage $\epsilon$ повноцінним учасником ринку і може обробляти вироблену енергію, продавати ії на ринку електроенергії за найвигіднішими цінами. Між усіма структурними елементами схеми відбувається обмін інформацією про рівень споживання та генерації в онлайн-режимі. Кожна із трьох моделей може бути залучена до планування та побудови моделі функціонування Energy Smart Community, з урахуванням сценарію їхньої роботи та граничних умов їх залучення до енергетичного й енергетичного планування [28].

\section{МОДЕЛЮВАННЯ ЕФЕКТИВНОСТІ РОБОТИ РУ-ПАНЕЛЕЙ}

Базову модель PV-панелі показано на рис. 2. Однодіодна модель фотоелектричної панелі представляється джерелом фотоструму і діодом, 3'єднаним із послідовними та шунтовими опорами [29].

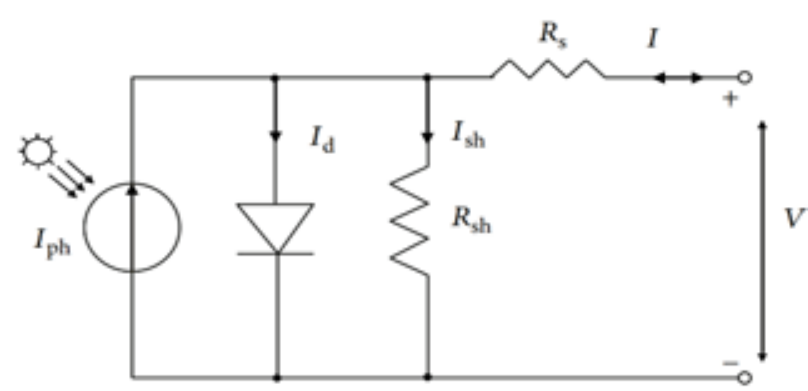

Рис. 2. Еквівалентна схема PV-панелі

Основні параметри електричної схеми базової панелі моделі PV можна описати такими формулами:

$$
\begin{gathered}
I_{P V}=I_{p h}-I_{s}\left(\exp \frac{\left(V+R_{s} I\right)}{A V_{T}}-1\right)-\frac{\left(V+I R_{s}\right)}{R_{s h}} \\
I_{p h}=I_{s c}+K_{i} \Delta T \frac{G}{1000} \\
I_{s}=\frac{I_{s c}+k_{i} \Delta T}{\exp \left(q \left(\left(V_{o c}+k_{o c}\left(\Delta T / A V_{T}\right)\right)-1\right.\right.} \\
V_{P V}=V_{i}+k_{V} T_{P V} \\
P_{P V}=N \cdot F F \cdot U_{P V} I_{P V} \\
F F=\frac{I_{M P P} V_{M P P}}{I_{i} V_{i}}
\end{gathered}
$$

Де у формулі (1): $I_{P V}-$ струм насичення діодом (A), $I_{s}$ - струм насичення діодом (A), $I_{p h}$ - фотострум на панелі (А), V - вихідна напруга панелі (V), $A$ - коефіцієнт ідеальності діода, $V_{T}=N_{s} K T / q$ - теплова напруга масиву із Ns-осередками, з'єднаними послідовно ( $K$ - постійна Больцмана, $\left.\mathrm{J} \cdot \mathrm{K}^{-1}\right), T$ - температура переходу $p-n,(\mathrm{~K}), q-$ заряд електрона $(\mathrm{C})))$, $R_{s}-$ серійний опір $(\Omega), R_{s h}-$ опір шунта $(\Omega)$.

У формулі (2): $I_{s c}$ - струм короткого замикання (A), $\Delta T=T-T_{n}\left(T\right.$ i $\left.T_{n}\right)$ - фактичні та номінальні температури (K), $K_{i}$ - коефіцієнт струму / температури короткого замикання $(\mathrm{K}), G$ - сонячне опромінення $\left(\mathrm{W} / \mathrm{m}^{2}\right)$.

У формулі (3) у рівняння включено коефіцієнти струму і напруги $k_{i}$ i $k_{O C} ; V_{O C}-$ це напруга відкритого контура (V).

У формулі (4): $V_{i}$ - коефіцієнт струму температури струму на холостому ходу, $\left(\mathrm{A} /{ }^{\circ} \mathrm{C}\right), T_{P V}-$ фактична температура на датчику PV-модуля.

У формулі (5): $\mathrm{P}_{P V}-$ вихідна активна потужність панелі (Watt), FF - коефіцієнт повного коефіцієнта; $V_{i}$ - напруга в режимі холостого ходу; струм короткого замикання о; $\mathrm{k}_{V}$ - коефіцієнт струму-температуpи, $\left(\mathrm{A} /{ }^{\circ} \mathrm{C}\right), \mathrm{TPV}$ - фактична температура на датчику модуля.

У формулі (6): $V_{M P P}$ - напруга під час пошуку максимальної точки напруги (V) (MPPT - Maximum power point tracker); $I_{M P P}-$ струм за МРPТ (A) [30].

\section{ВИКОРИСТАННЯ ПРОГРАМИ-АСИСТЕНТА ДЛЯ МОДЕЛЮВАННЯ РУ-СИСТЕМ}

Аналіз споживання електроенергії проводиться y MS Excel i використовується для подальшої синхронізації роботи з модулем Matlab Simulink. Важливо також отримати підсумкові показники енергетичних мереж, рекомендації щодо вибору обладнання та доцільності проєкту. У системі імітації використовуються такі безкоштовні онлайн-пакети програм, як PVGIS5 та Sunny Design.

Складові частини алгоритму моделювання (наведено на рис. 3) такі: Блок 1 - тип визначення моделі дослідження; Блок 2 - вхідні параметри прийому телеметричних та паспортних даних; 
Блок 3 - отримання змінних вхідних даних із цифрових лічильників; Блок 4 - розрахунок PV-системи в середовищі Matlab Simulink; Блок 5 - розрахунок споживання енергії для домашнього MS Excel; Блок 6 - отримання інформації про модульовану фотовольтаїчну установку, визначення прогнозованого обсягу виробленої та спожитої електроенергії; Блок 7 - за допомогою PVGIS 5 та Sunny Design Pro визначено показники технічної й економічної ефективності роботи моделі протягом обраного періоду, оптимальний вибір обладнання, але ми також можемо використовувати інші програмні продукти 3 таблиці 1 ; Блок 8 - досягнутий оптимальний варіант фіксації функціонування моделі; Блок 9 - визначення періоду окупності та вибір споживача, остаточне рішення щодо будівництва LES.

\section{ОБГОВОРЕННЯ ОТРИМАНИХ РЕЗУЛЬТАТІВ}

Використання програмного комплексу-асистента дозволяє широко оцінити роботу та майбутні показники сонячної електростанції для приватного будинку на етапі проєктування. Визначити можливі ризики та чинники впливу на систему щодо місцевості та/або розташування, шляхом використання безкоштовних програмних засобів.

\section{ВИСНОВКИ}

Описано методологію побудови та функціонування систем Energy Smart Community. Визначено завдання оптимізації використання електроенергії 3 енергосистеми. Описано сруктуру. Проведено аналіз ефективності PV-модулів за допомогою програмного модуля в системі Matlab Simulink. Визначено основні режими функціонування споживача як ключового елемента майбутнього розумного енергетичного середовища. Визначено залежності генерації електроенергії від впливу рівня сонячної інсоляції та перехресного будинкового затемнення.

Визначено основні режими функціонування активного споживача $з$ фотовольтаїчним елементаи генерації електроенергії як ключового елемента інтелектуального енергетичного середовища (Smart Community).

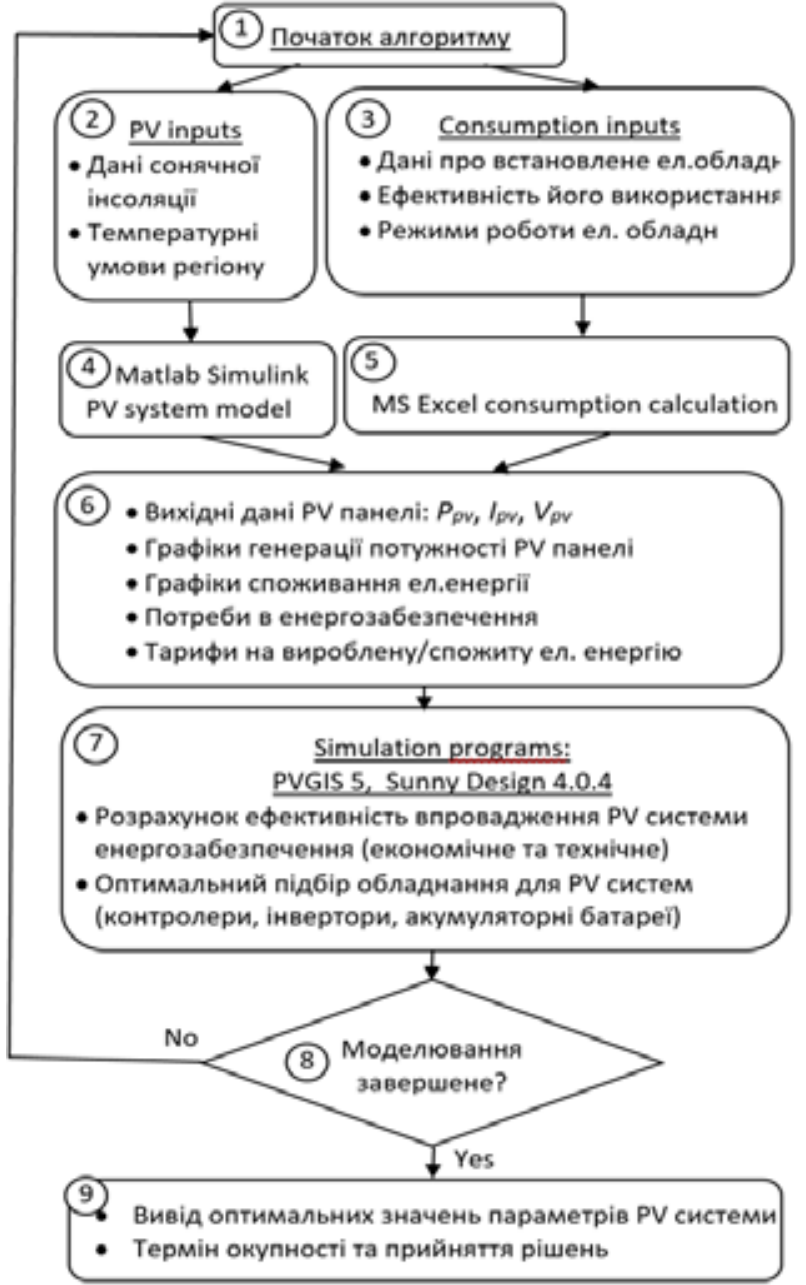

Рис. 3. Алгоритм проведення досліджень

Проведені розрахунки та дослідження дають змогу оцінити доцільності впровадження PV-систем для приватного домогосподарства і підтверджують перспективи подальшого використання розробленого програмного комплекса-асистента як додаткового програмного забезпечення виконання досліджень, пов'язаних із PV-системами.

\section{REFERENCES}

[1] Denysiuk S. (2019) Enerhetychnyy perekhid - vymohy yakisnykh zmin u rozvytku enerhetyky. [Energy transitionrequirements for qualitative changes in energy development] Enerhetyka: ekonomika, tekhnolohiyi, ekolohiya. № 1. S. 7-28.

[2] Denysiuk S., Targonsky V. (2017) Stalyy rozvytok enerhetky Ukrayiny u svitovykh vymirakh. [Sustainable development of Ukraine's energy sector in the world] Enerhetyka: ekonomika, tekhnolohiyi, ekolohiya. № 3. P. 7-31

[3] Denysiuk S., Targonsky V.A., Artemyev M.V. (2018) Lokal'ni elektroenerhetychni systemy z aktyvnym spozhyvachem: metody pobudovy ta alhorytmy yikh funktsionuvannya [Local electric power systems with an active consumer: construction methods and algorithms for their operation] Enerhetyka: ekonomika, tekhnolohiyi, ekolohiya. № 3. P. 7-22.

[4] Intelektual'ni elektrychni merezhi: elementy ta rezhymy [Intelligent electrical networks: elements and modes] (2016) Za zah. red. akad. NAN Ukrayiny O.V. Kyrylenka / Instytut elektrodynamiky NAN Ukrayiny. K.: In-t elektrodynamiky NAN Ukrayiny. P. 400.

[5] Aggregators - Barriers and External Impacts, prepared for Ofgem (Office of Gas and Electricity Markets). - PA Consulting Group. URL: https://www.ofgem.gov.uk/system/files/docs/2016/07/aggregators_barriers_and_exter nal_impacts_a_report_ by_pa_consulting_0.pdf.

[6] Silvestre D., Luisa M., Salvatore E., Sanseverino E., Gaetano Z., (2018). How Decarbonization, Digitalization and Decentralization are changing key power infrastructures. Renewable and Sustainable Energy Reviews, Elsevier, vol. 93 (C), P. $483-498$. 
[7] Enabling independent aggregation in the European electricity markets. Roles and Responsibilities: Keeping the BRP whole after a demand response event. (2015) Position Paper. - SEDC (Smart Energy Demand Coalition), URL: http://smartenergydemand.eu/wp-content/uploads/2015/02/SEDC-Enabling-Independent-Aggregation.pdf.

[8] Energy Council. Issues monitor. (2018) - WEC - p. 126.

[9] Energy Service Companies in the EU - Status review and recommendations for further market development with a focus on Energy Performance Contracting. (2017) European Union.

[10] Energy-as-a-Service. The lights are on. Is anyone home? (2019) Deloitte LLP. P. 20.

[11] Key Facts about the Energy Transition in Germany. - Berlin Energy Transition Dialogue (2019). Berlin, Germany. Energiewende-New Horizons. P. 12. URL: https://2019.energydialogue.berlin/wp-content/uploads/2019/02/BETD-2019_Flyer_WEB.pdf.

[12] Long-Term Energy Scenarios for the clean energy transition. First-year campaign findings May (2019) The International Renewable Energy Agency (IRENA). P. 12. URL: https://www.irena.org/-/media/Files/IRENA/Agency/Publication/2019/ May/IRENA_LTES_findings_2019.pdf.

[13] Perspectives for the Energy Transition. - OECD/IEA and IRENA (2017) URL: https://www.iea.org/publications/insights/ insightpublications/ PerspectivesfortheEnergyTransition.pdf.

[14] URL: https://mind.ua/publications/20202114-igor-petrik-desyat-najdeshevshih-elektrostancij-ne-stvoryuyut-najefektivnishoyienergosistemi.

[15] Ukrenergo. URL: https://ua.energy/.

[16] Guide house Insights. URL: https://www.navigantresearch.com/reports/energy-as-a-service.

[17] Finnish Energy Hub URL: www.finnishenergyhub.com/post.

[18] National Energy and Utilities Regulatory Commission. On the status of the renewable energy sector in the first quarter of 2019. URL: http://www.nerc.gov.ua.

[19] Pidsumky pershoho kvartalu 2020 roku (dlya SES pid zelenyy taryf) [Results of the first quarter of 2020 (for SES under the green tariff)]. URL: https://sun-energy.com.ua/news/zvit-ses-1-kvartal-2020.

[20] Prem'yer ministr pro zelenyy memorandum: Tse spil'na pozytsiya uryadu i VDE-investoriv [Prime Minister on green memorandum: This is a joint position of the government and RES investors]. URL: https://www.epravda.com.ua/ news/2020/06/11/661643/.

[21] Vstyhnuty do 2030 roku: chomu v Ukrayini sposterihayet'sya bum investytsiy v zelenu enerhetyku i shcho zminyt'sya na rynku v 2020 rotsi? [Have time by 2030: why is there a boom in investment in green energy in Ukraine and what will change in the market in 2020?]. URL: https://getmarket.com.ua/ua/news/vstignuti-do-2030-roku-chomu-v-ukrayini-sposterigayetsya-bum-investicij-v-zelenu-energetiku-i-sho-zminit-sya-na-rinku-v-2020-roci.

[22] Omine E., Hatta H. and Ueno T., (2016) A study of economic feasibility of Smart Community. - calculation of profit of Community Operator considering introduction of battery and co-generation systems, 2016 IEEE Power \& Energy Society Innovative Smart Grid Technologies Conference (ISGT), Minneapolis, MN, P. 1-5.

[23] Ożadowicz A. (2017) A New Concept of Active Demand Side Management for Energy Efficient Prosumer, Microgrids with Smart Building Technologies. Energies., Vip. 10 (11), p. 1771.

[24] NYSEG: About the Energy Smart Community - Tompkins county, URL: https://www.nysegsmartsolutions.com.

[25] Smart Community Aruba. URL: http://www.smartcommunityaruba.aw/about/.

[26] Wu Y., Gao J.J. and Yu L.R., (2009) Demand chain management - The new source of profit increase 16th International Conference on Industrial Engineering and Engineering Management, Beijing, P. 1483-1487.

[27] Denysiuk S., Strzelecki R., Opryshko V. (2016) The smart grid concept implementation by expanding the use of demand side managment and modern power electronic installations. Enerhetyka: ekonomika, tekhnolohii, ekolohiia. № 4 (46). PP. 7-17. ISSN: $1813-5420$

\section{СПИСОК ВИКОРИСТАНОЇ ЛІТЕРАТУРИ}

[1] Денисюк С.П. Енергетичний перехід - вимоги якісних змін у розвитку енергетики. Енергетика: економіка, технології, екологія. 2019. № 1. С. 7-28.

[2] Денисюк С.П., Таргонський В.А. Сталий розвиток енергетки України у світових вимірах. Енергетика: економіка, технології, екологія. 2017. № 3. С. 7-31.

[3] Денисюк С.П., Таргонський В.А., Артем'єв М.В. Локальні електроенергетичні системи 3 активним споживачем: методи побудови та алгоритми їх функціонування. Енергетика: економіка, технології, екологія. 2018. № 3. С. 7-22.

[4] Інтелектуальні електричні мережі: елементи та режими / за заг. ред. О.В. Кириленка. Київ : Ін-т електродинаміки НАН України, 2016. $400 \mathrm{c}$.

[5] Aggregators - Barriers and External Impacts, prepared for Ofgem (Office of Gas and Electricity Markets). PA Consulting Group. URL: https://www.ofgem.gov.uk/system/files/docs/2016/07/aggregators_barriers_and_exter nal_impacts_a_report_ by_pa_consulting_0.pdf.

[6] How Decarbonization, Digitalization and Decentralization are changing key power infrastructures / D. Silvestre et al. Renewable and Sustainable Energy Reviews. 2018. Elsevier. Vol. 93 (C). P. 483-498.

[7] Enabling independent aggregation in the European electricity markets. Roles and Responsibilities: Keeping the BRP whole after a demand response event. 2015. Position Paper. SEDC (Smart Energy Demand Coalition). URL: http://smartenergydemand.eu/wp-content/uploads/2015/02/SEDC-Enabling-Independent-Aggregation.pdf. 
[8] Energy Council. Issues monitor. 2018. WEC. P. 126.

[9] Energy Service Companies in the EU : Status review and recommendations for further market development with a focus on Energy Performance Contracting. 2017. European Union.

[10] Energy-as-a-Service. The lights are on. Is anyone home? 2019. Deloitte LLP. P. 20.

[11] Key Facts about the Energy Transition in Germany. Berlin Energy Transition Dialogue. 2019. Berlin, Germany. Energiewende - New Horizons. P. 12. URL: https://2019.energydialogue.berlin/wp-content/uploads/2019/02/BETD-2019_Flyer_ WEB.pdf.

[12] Long-Term Energy Scenarios for the clean energy transition. First-year campaign findings May. 2019. The International Renewable Energy Agency (IRENA). P. 12. URL: https://www.irena.org/-/media/Files/IRENA/Agency/Publication/2019/ May/IRENA_LTES_findings_2019.pdf.

[13] Perspectives for the Energy Transition. OECD/IEA and IRENA. 2017. URL: https://www.iea.org/publications/insights/ insightpublications/ PerspectivesfortheEnergyTransition.pdf.

[14] URL: https://mind.ua/publications/20202114-igor-petrik-desyat-najdeshevshih-elektrostancij-ne-stvoryuyut-najefektivnishoyienergosistemi.

[15] Укренерго. URL: https://ua.energy/

[16] Guide house Insights. URL: https://www.navigantresearch.com/reports/energy-as-a-service.

[17] Finnish Energy Hub. URL: www.finnishenergyhub.com/post.

[18] National Energy and Utilities Regulatory Commission. On the status of the renewable energy sector in the first quarter of 2019. URL: http://www.nerc.gov.ua.

[19] Підсумки першого кварталу 2020 р. (для CEC під зелений тариф). URL: https://sun-energy.com.ua/news/zvit-ses-1kvartal-2020.

[20] Прем’єр про зелений меморандум: Це спільна позиція уряду і ВДЕ-інвесторів. URL: https:/www.epravda.com.ua/ news/2020/06/11/661643/.

[21] Встигнути до 2030 р. : чому в Україні спостерігається бум інвестицій в зелену енергетику і що зміниться на ринку у 2020 p.? URL: https://getmarket.com.ua/ua/news/vstignuti-do-2030-roku-chomu-v-ukrayini-sposterigayet-sya-buminvesticij-v-zelenu-energetiku-i-sho-zminit-sya-na-rinku-v-2020-roci.

[22] Omine E., Hatta H., Ueno T. A study of economic feasibility of Smart Community. Calculation of profit of Community Operator considering introduction of battery and co-generation systems : 2016 IEEE Power \& Energy Society Innovative Smart Grid Technologies Conference (ISGT), 2016. Minneapolis, MN. P. 1-5.

[23] Ożadowicz A. A New Concept of Active Demand Side Management for Energy Efficient Prosumer, Microgrids with Smart Building Technologies. Energies. 2017. V. 10 (11). P. 1771.

[24] NYSEG: About the Energy Smart Community - Tompkins county, URL: https://www.nysegsmartsolutions.com.

[25] Smart Community Aruba. URL: http://www.smartcommunityaruba.aw/about/.

[26] Wu Y., Gao J.J., Yu L.R. Demand chain management - The new source of profit increase : 16th International Conference on Industrial Engineering and Engineering Management. 2009. Beijing. P. 1483-1487.

[27] Denysiuk S., Strzelecki R., Opryshko V. The smart grid concept implementation by expanding the use of demand side managment and modern power electronic installations. Енергетика: економіка, технології, екологія. 2016. № 4 (46). C. 7-17. ISSN: 1813-5420.

[28] Про встановлення зелених тарифів на електричну енергію для приватних домогосподарств : постанова. URL: https://zakon.rada.gov.ua/laws/show/z1022-16.

[29] Keshtkar A., Arzanpour S., Keshtkar F. Adaptive residential demand-side management using rule-based.

(C) С. П. Денисюк, П. В. Соколовський Дата надходження статті до редакції: 12.06 .2020 Дата затвердження статті до друку: 10.07.2020 